\title{
SIFAT ORGANOLEPTIK DAN INDEKS GLIKEMIK PRODUK SORGUM BAR YANG DIFORMULASI MENGGUNAKAN BERBAGAI JENIS PENYALUT NIRA
}

\section{Organoleptic Properties and Glycemic Index of Sorghum Bar Products Formulated Using Different Types of Sugar Syrup Coating}

\author{
Nur Avidha Surayya ${ }^{1}$, Maulidia Hilaili ${ }^{1}$, Elvia Rahmawati ${ }^{1}$, Elinna Primadiani ${ }^{1}$, Jamaluddin Asy \\ Syauqi ${ }^{2}$, Anggara Nur Rushydi ${ }^{2}$, Siti Narsito Wulan ${ }^{1 *}$ \\ 1) Jurusan Teknologi Hasil Pertanian, FTP Universitas Brawijaya Malang \\ 2) Jurusan Teknologi Industri Pertanian, FTP Universitas Brawijaya Malang \\ Jl. Veteran, Malang 65145 \\ *Penulis Korespondensi, Email: wulan_thpub@ub.ac.id
}

\begin{abstract}
ABSTRAK
Diabetes Mellitus (DM) merupakan penyakit dimana tubuh mengalami gangguan metabolisme glukosa dan penggunaan insulin secara efektif. Sorgum merupakan serealia dengan kandungan gizi tinggi serta kaya pati resisten dan senyawa polifenol seperti proanthocyanidin (tannin terkondensasi). Sorgum dapat dijadikan bahan utama pembuatan makanan selingan (snack) penderita DM tipe 2 dengan berbentuk batangan/ bar yang dilapisi penyalut glucose syrup, karamel nira sorgum atau karamel nira tebu. Tujuan dari penelitian ini adalah menemukan formulasi sorgum bar yang memiliki Indeks Glikemik (IG) rendah dengan berbagai penyalut. Pada pengujian organoleptik metode Hedonic test dengan 80 panelis, formulasi $20 \%$ penyalut lebih disukai. Sorgum bar diuji kemampuannya meningkatkan respon glukosa darah pada 12 responden orang sehat pada waktu ke-0, 30, 60, 90, dan 120 menit untuk mengetahui nilai IG. Indeks Glisemik sorgum-bar berpenyalut karamel nira sorgum 45.04 (terendah), karamel nira tebu 53.72, dan glucose syrup 81.41 .
\end{abstract}

Kata kunci: Diabetes Millitus, Indeks Glikemik, Nira sorgum, Nira tebu, Sorgum Bar

\begin{abstract}
Diabetes Mellitus (DM) is a metabolic disorder where the body cannot use insulin effectively. Sorghum is a cereal with a high nutritional content, high resistant starch and high polyphenolic compounds such as proanthocyanidins (condensed tannins). Sorghum can be utilized as a main ingredient for snack bars intended to be consumed by DM type 2 patients. The purpose of this study was to determine sorghum bar's formulation with low Glycemic Index (GI). In organoleptic test performed by 80 panelists results showed that 20\% coating formulation was the most preferred. Sorghum bars with different coating formulation were tested for blood glucose response at 0, 30, 60, 90, and 120 minutes to determine Gl by using 12 healthy volunteers. Glycemic Index of sorghum bar differed in coating were as follows: coated with caramel sorghum syrup was 45.04 (the lowest), caramel sugarcane syrup was 53.72, and glucose syrup was 81.41 .
\end{abstract}

Keywords: Diabetes Millitus, Glycemic index, Sorghum juice, Sorghum bar, Sugarcane juice

\section{PENDAHULUAN}

Diabetes Mellitus adalah penyakit gangguan metabolisme glukosa akibat kurangnya produksi insulin ataupun kurang sensitifnya jaringan terhadap kerja hormon (aksi) insulin dalam memfasilitasi masuknya glukosa ke dalam sel atau kedua-duanya yang akan memburuk dengan adanya degenerasi sel beta pancreas (ADA, 2012). Penderita diabetes di Indonesia berjumlah 8.426.000 jiwa di tahun 2000, tertinggi di Asia Tenggara dan diproyeksikan 
meningkat 2.5 kali lipat menjadi 21.257 .000 penderita pada tahun 2030 (WHO, 2016). Salah satu penyebab tingginya prevalensi diabetes mellitus yaitu mengkonsumsi makanan yang tidak tepat khususnya makanan yang tinggi kalori (Franz, 2008). Kadar gula yang tinggi pada suatu makanan yang dikonsumsi dapat menyebabkan kenaikan gula darah secara cepat dalam tubuh manusia (Goff and Dyson, 2016). Salah satu upaya untuk mengendalikan kadar glukosa darah yakni mengatur dan memonitor asupan karbohidrat baik jumlah maupun jenisnya, salah satunya dengan mengacu pada nilai Indeks Glikemik (IG) makanan/produk pangan.

Sorgum merupakan tanaman serealia khas Indonesia yang dapat diolah menjadi produk makanan dengan IG rendah. Menurut Kementerian Pertanian (2015), komoditas sorgum mampu tumbuh baik di Indonesia dengan iklim tropis dan memiliki luas tanam $2.62 \mathrm{Ha}$ dengan luas panen $2600 \mathrm{Ha}$ dan produksi sejumlah 7.800 ton di beberapa daerah salah satunya Lamongan, Jawa Timur. Sorgum memiliki kandungan gizi tinggi yaitu kadar abu 1,43 g, protein $10.62 \mathrm{~g}$, lemak $3.46 \mathrm{~g}$, serat $6.70 \mathrm{~g}$, karbohidrat $72.09 \mathrm{~g}$, total energi $329 \mathrm{kal}$ per $100 \mathrm{~g}$ (USDA, 2016). Biji sorgum memiliki nilai indeks glikemik (IG) sebesar 46.8 yang tergolong dalam IG rendah < 55 (Taylor and Duodu, 2019). Selain bijinya, nira sorgum juga dapat dimanfaatkan dalam pembuatan karamel sebagai bahan penyalut karena memiliki rasa yang manis seperti nira tebu. Nira sorgum memiliki nilai TPT (brix) \pm 15.77 (Rahman, dkk., 2019) dan memiliki nilai IG yang rendah yaitu 50 (Calbom, 2016). Nilai IG yang rendah pada biji dan nira sorgum serta ketersediaan komoditas lokal ini menjadi peluang besar dalam pengolahan sorgum menjadi bahan baku produk pangan berupa snack bars sebagai solusi alternatif makanan ringan penderita DM T2. Selain itu juga digunakan pembanding nira tebu dan glucose syrup untuk mengetahui perbedaan nilai indeks glikemik ketiga produk dengan jenis penyalut yang berbeda.

Pada penelitian ini, snack bars akan dibuat dengan bahan dasar biji sorgum diproses dengan ekstruder menjadi sorgum puff dan dilapisi dengan menggunakan karamel nira sorgum, nira tebu, dan glucose syrup sebagai penyalutnya. Produk sorgum bar diuji organoleptik untuk mendapatkan formulasi terbaik yang dapat diterima oleh panelis. Uji indeks glikemik pada manusia setelah mengkonsumsi produk sorgum bar dilakukan untuk mengetahui kemampuan produk dalam meningkatkan kadar glukosa darah sehingga dapat diketahui apakah dapat dikategorikan sebagai makanan alternatif yang aman untuk dikonsumsi penderita diabetes tipe-2. Penelitian ini memiliki kontribusi terhadap peningkatan diversifikasi pangan dalam pengembangan potensi komoditas lokal yaitu sorgum sebagai pangan fungsional untuk solusi alternatif makanan penderita diabetes mellitus tipe 2.

\section{BAHAN DAN METODE}

\section{Bahan}

Bahan baku pembuatan sorgum bar adalah biji sorgum, sedangkan bahan untuk penyalut adalah nira sorgum dan nira tebu yang kesemuanya didapat dari Lamongan, Jawa Timur. Bahan tambahan yakni madu merk TS Bebas Gula dan sereal Oat yang didapat dari supermarket Lai Lai, serta pelapis cetakan yakni alumunium foil. Bahan yang digunakan untuk uji hedonik yakni sorgum bar, cup kertas warna putih, dan air mineral $120 \mathrm{ml}$. Bahan untuk analisis Indeks Glikemik yakni alkohol 70\%, air mineral $250 \mathrm{ml}$, kapas, strip On Call Platinum, sarung tangan, dan glukosa anhidrat food grade yang didapat dari toko Panadia, Malang.

\section{Alat}

Pada penelitian ini menggunakan mesin ekstruder ulir ganda (Kowa tipe KEI 25, Japan), timbangan analitik (Denver instrument M-310), oven konvensional, cetakan berbahan stainless steel berukuran $5 \mathrm{~cm} \times 2 \mathrm{~cm}$, alat tes glukosa darah (On Call Platinum), Injektor berukuran 10 $\mathrm{ml}$.

\section{Desain Penelitian}

Penelitian ini dilakukan dalam dua tahap percobaan, uji organoleptik dilakukan untuk menentukan produk yang paling disukai oleh panelis diantara dua hasil formulasi pada penyalut yang berbeda yakni karamel nira sorgum, karamel nira tebu, dan glucose syrup menggunakan Rancangan Acak Kelompok. Tahap selanjutnya untuk mengetahui respon gula darah setelah mengkonsumsi produk yang paling disukai oleh panelis pada masing-masing jenis penyalut 
untuk penentuan indeks glikemik produk sorgum bar. Analisis data uji organoleptik dengan melihat trend data pada spider chart dengan faktor perbedaan konsentrasi penyalut. Untuk uji indeks glikemik menggunakan sebanyak 12 subyek yang mengkonsumsi sorgum bar dengan perbedaan jenis penyalut. Data hasil pengamatan tersebut selanjutnya dianalisis dengan metode ANOVA (Analysis of Variance) pada aplikasi Minitab 17 dengan derajat kepercayaan $95 \%$.

\section{Tahapan Penelitian}

Penelitian ini diawali dengan melakukan pembuatan sorgum puff dengan mesin ekstruder ulir ganda kemudian dilanjutkan dengan pembuatan karamel sebagai bahan perekat dari nira sorgum dan nira tebu serta glucose syrup yang merupakan penyalut komersial lalu dicampur hingga menjadi produk sorgum bar. Produk sorgum bar kemudian diuji organoleptik untuk mendapatkan formulasi terbaik yang diterima panelis kemudian dilakukan uji proksimat untuk mendapatkan nilai karbohidrat by difference dan serat kasar yang digunakan untuk perhitungan jumlah asupan setara $50 \mathrm{~g}$ glukosa untuk pengujian nilai indeks glikemik produk.

\section{Metode Penelitian}

Tahap pertama dari penelitian ini adalah pembuatan sorgum puff menggunakan mesin ekstruder ulir ganda dengan suhu pada cylinder 1 yakni $38^{\circ} \mathrm{C}$, cylinder 2 yakni $62{ }^{\circ} \mathrm{C}$, cylinder 3 yakni $91{ }^{\circ} \mathrm{C}$, cylinder $4144^{\circ} \mathrm{C}$, dan adaptor $151{ }^{\circ} \mathrm{C}$. Selanjutnya, pembuatan karamel nira sorgum dan tebu dengan cara dipress menggunakan mesin gilingan dan nira yang telah bersih dievaporasi dengan suhu $80{ }^{\circ} \mathrm{C}$ selama 37 menit hingga menjadi karamel nira. Kemudian, pembuatan produk sorgum bar dengan mencampur bahan sesuai formulasi pada Tabel 1. Seluruh bahan dicampur menjadi satu pada wadah kemudian dicetak pada cetakan berukuran 5 $\mathrm{cm} \times 2 \mathrm{~cm}$ yang telah dilapisi dengan alumunium foil. Seluruh bahan yang telah dimasukkan cetakan dioven menggunakan oven konvensional suhu $120{ }^{\circ} \mathrm{C}$ selama 10 menit. Produk dilakukan uji organoleptik untuk memilih konsentrasi penyalut produk sorgum bar yang disukai konsumen. Pengujian klinik indeks glikemik produk sorgum bar dengan berbagai penyalut dilakukan di Poliklinik Universitas Brawijaya terhadap 12 orang subyek. Pengujian klinik telah mendapatkan persetujuan etik dari Komisi Etik Penelitian Kesehatan Politeknik Kesehatan KEMENKES Malang dengan kelayakan etik No 477/KEPK-POLKESMA/2019 Tanggal 4 Oktober 2019, pengambilan sampel darah subyek untuk penentuan indeks glisemik produk sorgum bar dilaksanakan pada 26 November - 20 Desember 2019. Formulasi produk sorgum bar dapat dilihat pada Tabel 1.

Tabel 1. Formulasi Sorgum Bar Terpilih

\begin{tabular}{lcc}
\hline \multicolumn{1}{c}{ Bahan } & \multicolumn{2}{c}{ Komposisi Bahan Baku } \\
\cline { 2 - 3 } & I & II \\
\hline Sorgum * & $60 \%$ & $50 \%$ \\
Oat & $20 \%$ & $20 \%$ \\
Penyalut* & $10 \%$ & $20 \%$ \\
Madu & $10 \%$ & $10 \%$ \\
*Sorgum : dibuat sorgum puff dry & \\
*Penyalut $\quad$ : dibuat karamel dari nira sorgum, nira tebu, dan glucose syrup
\end{tabular}

\section{Prosedur Analisis}

1. Uji Organoleptik

Pengujian organoleptik untuk menentukan formulasi yang disukai oleh panelis. Rancangan yang digunakan pada pengujian organoleptik yakni Rancangan Acak Kelompok yakni dibagi menjadi dua hari, hari pertama menggunakan 40 panelis hari kedua dilanjutkan 40 panelis sehingga total menjadi 80 panelis. Uji organoleptik menggunakan response atribut rasa, warna, aroma, dan kerenyahan. Pada pengujian organoleptik digunakan metode Uji Hedonik dimana panelis memberikan nilai kesukaan mulai skor $1-5$ tanpa membandingkan antar sampel. Faktor pada uji hedonik yakni proporsi sorgum puff, proporsi penyalut, dan perbedaan 
jenis penyalut yakni menggunakan kedua formulasi yang ada pada tabel 1. Uji organoleptik dianalisis trend data menggunakan spider chart.

\section{Uji Indeks Glikemik}

Setiap porsi penyajian produk snack bar yang telah terpilih pada uji organoleptik akan ditentukan indeks glikemiknya dengan kandungan setara 50 gram available karbohidrat. Pengujian dilakukan pada hari Selasa hingga Jum'at setiap minggunya selama 4 minggu. Pengujian respon glukosa darah setiap produk dilakukan secara terpisah diberi antara $1 \mathrm{minggu}$ (total 4 minggu, untuk menguji 3 produk sorgum bar dengan 3 jenis penyalut dan 1 pangan acuan larutan glukosa anhidrat). Subyek (responden) datang untuk diperiksa respon glukosa darahnya setelah mengkonsumsi pangan uji atau pangan acuan pada hari yang sama setiap minggunya selama 4 minggu. Produk sorgum bar dikonsumsi oleh relawan yang 10 jam sebelumnya telah menjalani puasa penuh (kecuali air). Panelis terdiri dari 12 responden. Sebelum konsumsi produk, responden diambil darahnya melalui ujung jari (finger prick capillary blood sample method) sebanyak $50 \mu \mathrm{L}$. Hasil pengukuran kadar glukosa darah yang diteteskan pada glucose-strip selanjutnya dibaca pada Gluco-meter digital dan menunjukkan kadar glukosa darah puasa (menit ke-0). Setelah responden mengkonsumsi sorgum bar dengan berbagai jenis penyalut (sesuai jadwal pengujian), sampel darah responden kembali diambil pada menit ke-30, 60, 90, dan 120 dengan alat yang sama (Aviyanty, 2014).Kadar glukosa darah pada menit ke-0, 30, 60, 90 dan 120 dicatat untuk setiap responden dan setiap jenis produk/pangan uji atau pangan acuan. Data ini nantinya akan digunakan untuk membuat kurva respon glikemik terhadap pangan yang diuji. Responden juga diberikan glukosa murni (glukosa anhydrat) sebagai standar. Indeks glikemik dihitung berdasarkan rasio antara luas daerah dibawah kurva (AUC: area under the curve) dari pangan yang diukur IG nya dengan acuan berupa larutan glukosa murni dikalikan 100. Kriteria inklusi subjek yaitu memiliki indeks massa tubuh normal antara $18.2-24.9 \mathrm{~kg} / \mathrm{m}^{2}$, berusia 20-30 tahun, tidak merokok atau minum alkohol, tidak mempunyai riwayat penyakit metabolik seperti diabetes, kadar glukosa darah puasa $<100$, bersedia puasa selama 10 jam. Teknik perekrutan subyek secara purposive sampling.

Respon glukosa darah setelah mengkonsumsi bahan pangan diamati selama 2 jam dan hasilnya diplotkan pada sumbu (x) menunjukkan waktu pengukuran (menit) setiap 30 menit dan ordinat (y) menunjukkan kadar gula darah $(\mathrm{mg} / \mathrm{dl})$ yang diamati. Nilai indeks glikemik dihitung dengan membandingkan luas kurva respon glukosa darah setelah mengkonsumsi pangan uji dan setelah mengkonsumsi larutan glukosa anhidrat sebagai standard (pangan acuan). Masing-masing responden ditentukan nilai indeks glikemiknya yang kemudian dirata-rata untuk didapatkan nilai indeks glikemik masing-masing pangan uji (produk sorgum bar dengan berbagai penyalut). Rumus perhitungan Indeks Glikemik menurut Rakhmawati (2011) :

$$
I G=\frac{\text { AUC Sampel }}{\text { AUC glukosa standar }} \times 100
$$

$$
\text { Jumlah porsi }(g)=\frac{50 \mathrm{~g} \times 100}{\text { karbohidrat by different-serat pangan }}
$$

\section{HASIL DAN PEMBAHASAN}

\section{Sifat Organoleptik Produk Sorgum Bar}

Pengujian organoleptik dilakukan untuk menentukan formulasi yang tepat antara proporsi sorgum puff dengan penyalut. Uji Organoleptik menggunakan metode Hedonik untuk menentukan formulasi terbaik yang disukai panelis. Formulasi yang diuji yakni formulasi I dengan komponen $60 \%$ sorgum puff, $20 \%$ oats, madu $10 \%$, penyalut $10 \%$ penyalut dan Formulasi II dengan komponen $50 \%$ sorgum puff, $20 \%$ oats, madu $10 \%$, $20 \%$ penyalut. Jenis penyalut yang digunakan adalah karamel nira sorgum, karamel nira tebu, dan glucose syrup. Uji Organoleptik menggunakan 80 panelis tidak terlatih dengan atribut yang diujikan meliputi: Rasa, Aroma, Warna, dan Kerenyahan. Hasil uji organoleptik disajikan pada Gambar 1, Gambar 2, dan Gambar 3. 


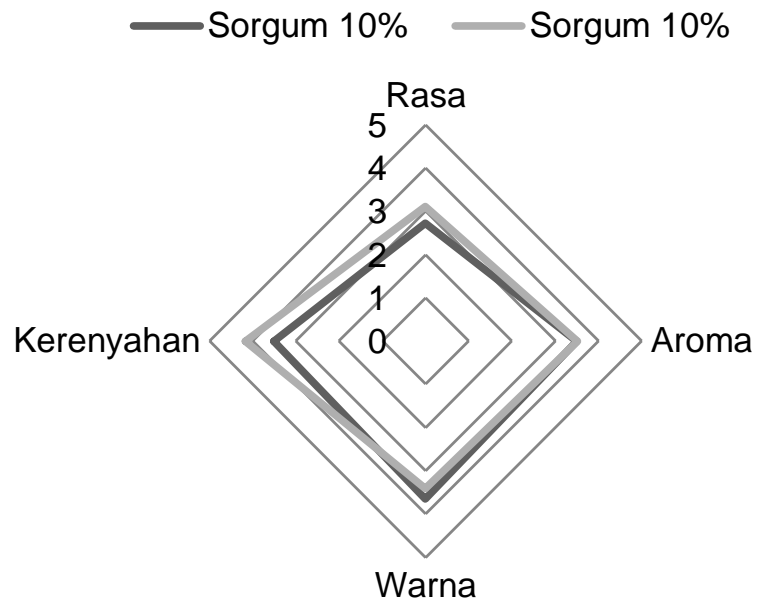

Gambar 1. Sorgum bar menggunakan penyalut nira sorgum

Berdasarkan spider chart (Gambar 1) didapatkan hasil bahwa sorgum bar yang menggunakan penyalut nira sorgum $20 \%$ lebih disukai jika dibandingkan dengan sorgum bar yang menggunakan penyalut nira sorgum $10 \%$. Sorgum bar dengan penyalut nira sorgum $20 \%$ lebih disukai karena rasa manis yang cukup, aroma karamel yang lebih kuat, tekstur yang lebih renyah ketika digigit (crunchy), namun dalam segi warna tidak lebih disukai dikarenakan warna sorgum puff menggunakan penyalut nira sorgum $20 \%$ mempunyai warna cenderung lebih gelap dibandingkan sorgum puff menggunakan penyalut nira sorgum $10 \%$. Sorgum bar menggunakan penyalut nira sorgum yang dipilih adalah penyalut nira sorgum $20 \%$ untuk kemudian dilanjukan uji Indeks Glikemik.

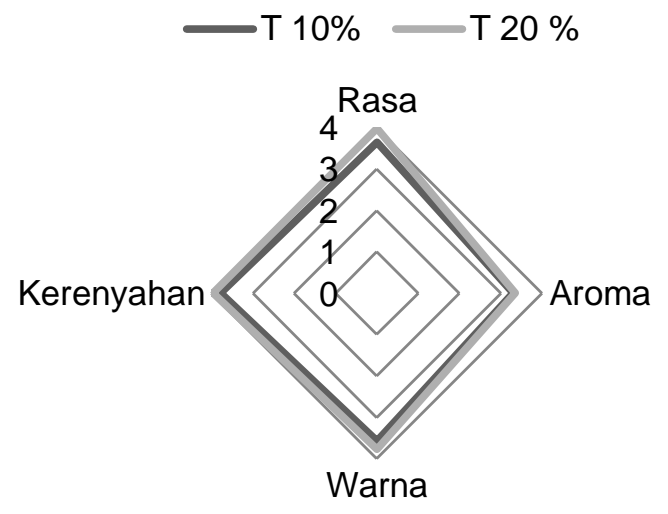

Gambar 2. Sorgum bar menggunakan penyalut nira tebu

Berdasarkan spider chart (Gambar 2) didapatkan hasil bahwa sorgum bar yang menggunakan penyalut nira tebu $20 \%$ lebih disukai jika dibandingkan dengan sorgum bar yang menggunakan penyalut nira tebu $10 \%$. Sorgum bar dengan penyalut nira tebu $20 \%$ lebih disukai karena memiliki rasa manis yang cukup, aroma karamel dari nira yang kuat, tekstur yang lebih renyah ketika digigit (crunchy), dan warna yang lebih disukai karena memiliki warna kecoklatan yang sesuai dengan keinginan konsumen (reaksi maillard sempurna) jika dibandingkan dengan sorgum puff yang menggunakan penyalut nira tebu $10 \%$. Sorgum bar menggunakan penyalut nira tebu yang dipilih adalah penyalut nira tebu $20 \%$ untuk kemudian dilanjukan uji Indeks Glikemik. 


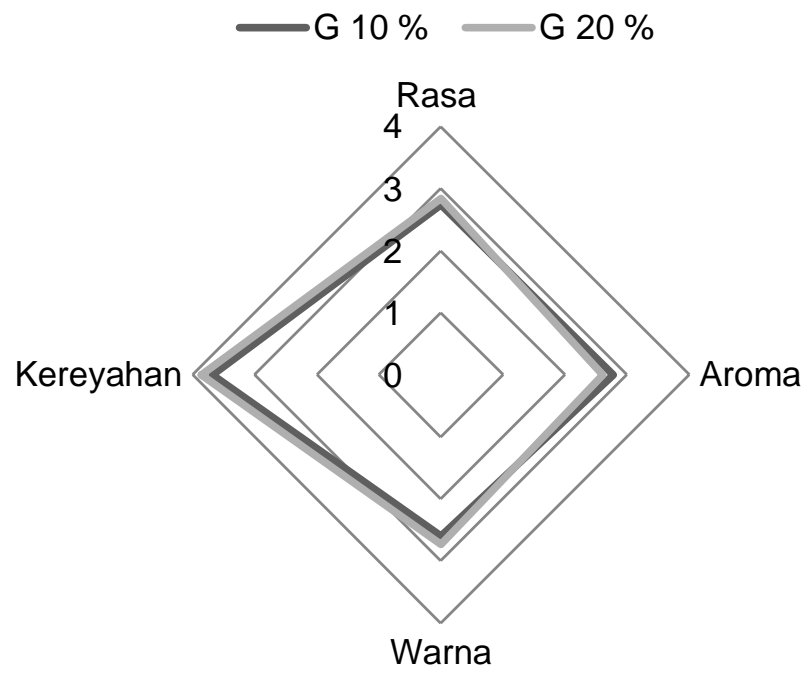

Gambar 3. Sorgum bar menggunakan Glucose syrup

Berdasarkan spider chart (Gambar 3) didapatkan hasil bahwa sorgum bar yang menggunakan penyalut glucose syrup $20 \%$ lebih disukai jika dibandingkan dengan sorgum bar yang menggunakan penyalut glucose syrup 10\%. Sorgum bar dengan penyalut glucose syrup $20 \%$ lebih disukai karena memiliki rasa yang lebih manis serta bertekstur renyah ketika digigit (crunchy). Selain itu, warnanya lebih disukai dengan rasa manis yang lebih terasa, bertekstur renyah ketika digigit atau dipatahkan (crunchy), dan warna kecoklatan hasil reaksi maillard yang menarik dan sesuai dengan keinginan konsumen, namun tidak lebih disukai dalam segi aroma jika dibandingkan dengan sorgum puff yang menggunakan penyalut glucose syrup 10\%. Sorgum bar menggunakan penyalut glucose syrup yang dipilih adalah penyalut glucose syrup $20 \%$ untuk kemudian dilanjukan uji Indeks Glikemik.

\section{Komposisi Kimia Produk Sorgum Bar}

Bersadarkan hasil analisis proximat pada sorgum bar dengan berbagai macam penyalut konsentrasi $20 \%$ dan sorgum puff (tanpa penyalut) diperoleh kadar protein, lemak, abu, air, karbohidrat by difference, dan serat kasar. Komposisi selengkapnya disajikan pada Tabel 2.

Tabel 2. Komposisi kimia sorgum puff dan sorgum bar dengan berbagai macam penyalut

\begin{tabular}{lcccc}
\hline Komposisi Kimia & $\begin{array}{c}\text { Sorgum bar } \\
\text { (Nira Sorgum 20\%) }\end{array}$ & $\begin{array}{c}\text { Sorgum bar } \\
\text { (Nira Tebu 20\%) }\end{array}$ & $\begin{array}{c}\text { Sorgum bar } \\
\text { (Sirup Glucose 20\%) }\end{array}$ & Sorgum Puft \\
\hline Protein (\%) & $6.30 \pm 0.02$ & $6.12 \pm 0.04$ & $5.42 \pm 0.02$ & $7.36 \pm 0.05$ \\
Lemak (\%) & $1.88 \pm 0.06$ & $1.62 \pm 0.01$ & $1.83 \pm 0.02$ & $0.23 \pm 0.07$ \\
Air (\%) & $6.24 \pm 0.03$ & $4.10 \pm 0.04$ & $5.14 \pm 0.01$ & $8.01 \pm 0.10$ \\
Abu (\%) & $2.39 \pm 0.04$ & $0.99 \pm 0.13$ & $0.82 \pm 0.03$ & $1.00 \pm 0.05$ \\
Karbohidrat (\%) & $83.19 \pm 0.06$ & $87.17 \pm 0.06$ & $86.79 \pm 0.04$ & $83.40 \pm 0.26$ \\
$\quad$ - Serat Kasar (\%) & $0.94 \pm 0.03$ & $0.77 \pm 0.02$ & $0.89 \pm 0.03$ & $0.93 \pm 0.03$ \\
\hline
\end{tabular}

\section{Kadar Protein Produk}

Protein berfungsi sebagai zat pembangun sel, dan zat pengatur di dalam tubuh manusia (Muchtadi et al, 2006). Protein dalam bentuk asam amino diserap oleh tubuh dan setiap asam amino selalu memiliki unsur nitrogen. Jumlah nitrogen yang terdapat pada asam amino dapat digunakan sebagai penentu kadar protein.

Kadar protein akan berbeda-beda tergantung dari bahan utama penyusun pangan tersebut. Berdasarkan Tabel 2. Sorgum puff memiliki kadar protein $7.36 \%$ bb, sorgum bar dengan penyalut nira sorgum memiliki kadar protein $6.30 \% \mathrm{bb}$, sorgum bar dengan penyalut nira tebu memiliki kadar protein $6.12 \% \mathrm{bb}$, dan sorgum bar dengan penyalut glucose syrup memiliki kadar protein $5.42 \%$ bb. Penambahan penyalut yang berupa nira atau sirup glukosa 
dengan komponen utama gula sederhana secara keseluruhan menurunkan kadar protein produk.

\section{Kadar Lemak Produk}

Lemak tersusun dari trigliserida sebagai komponen utama dan juga fosfolipid dan sterol. Lemak merupakan komponen tidak larut air (non-polar). Lemak merupakan sumber energi yang memiliki nilai energi lebih besar jika dibandingkan dengan protein dan karbohidrat, yaitu sebesar 9,0 kkal per gram. Lemak memiliki fungsi sebagai pelarut dalam tubuh, pembawa vitamin $(A, D, E, K)$, serta sebagai peningkat palatabilitas (Muchtadi et al, 2006).

Berdasarkan Tabel 2. sorgum bar dengan penyalut nira sorgum memiliki kadar lemak sebesar $1.88 \%$, sorgum bar dengan penyalut glucose syrup sebesar $1.83 \%$, sorgum bar dengan penyalut nira tebu $1.62 \%$ dan sorgum puff sebesar $0.23 \%$.

\section{Kadar Air Produk}

Kadar air yaitu jumlah air yang terkandung pada produk. Kadar air dapat menurunkan mutu suatu produk pangan secara kimia maupun mikrobiologi. Semakin tinggi air yang terkandung pada produk pangan meningkatkan Aw produk yang sesuai untuk pertumbuhan mikroba, memfasilitasi pencoklatan enzimatis atau hidrolisis lemak (Amanto Sigit, et al, 2015).

Berdasarkan Tabel 2. Sorgum puff memiliki kadar air sebesar $8.01 \%$, sorgum bar dengan penyalut nira sorgum yaitu $6.24 \%$, sorgum bar dengan penyalut glucose syrup sebesar $5.14 \%$, dan sorgum bar dengan penyalut nira tebu sebesar $4.10 \%$. Sorgum puff bersifat sangat higrokopis atau mudah mengikat air selama pengolahan menjadi sorgum bar.

\section{Kadar Abu Produk}

Kadar abu menggambarkan kadar mineral yang terdapat pada produk pangan tersebut.. Jumlah mineral dalam bahan pangan tidak diperbolehkan melebihi $4 \%$ dari total berat makanan (Nabryzki, 2002). Berdasarkan Tabel 2. sorgum bar dengan penyalut nira sorgum memiliki kadar abu $2.39 \%$, kemudian sorgum puff sebesar $1 \%$, sorgum bar dengan penyalut nira tebu sebesar $0.99 \%$, dan sorgum bar dengan penyalut glucose syrup $0.82 \%$. Kadar abu dari snack bar dengan bahan dasar tepung sorgum berkisar 1.47\% - 2.17\% (Rufaizah, 2011). Adanya perbedaan dengan literatur dapat disebabkan oleh jenis sorgum yang digunakan, proses pengolahan snack bar, dan jenis penyalut bar (Sari, et al., 2015).

\section{Kadar Karbohidrat Produk (by difference)}

Karbohidrat dalam produk pangan merupakan komponen organik yang tersusun atas karbon, oksigen, dan hidrogen yang tersusun secara sederhana maupun kompleks. Karbohidrat terkandung banyak pada bahan pangan seperti: pati, gula, pektin dan selulosa. Pengukuran kadar karbohidrat pada bahan pangan salah satunya menggunakan metode by difference (Almatsier, 2001).

Berdasarkan Tabel 2. sorgum bar dengan penyalut nira tebu memiliki kadar karbohidrat sebesar $87.17 \%$, sorgum bar dengan penyalut glucose syrup sebesar $86.79 \%$, sorgum puff sebesar $83.40 \%$, dan sorgum bar dengan penyalut nira sorgum sebesar $83.19 \%$. Berdasarkan penelitian sebelumnya snack bar dengan bahan baku tepung sorgum memiliki kadar karbohidrat sebesar $70.92 \%$ sampai $91.10 \%$. Semakin tinggi kadar karbohidrat dapat menjadi indikator bagi nilai Indeks Glikemik (IG) (Septiani et al., 2012). Perbedaan kadar karbohidrat yang terkandung pada sorgum bar tersebut dipengaruhi oleh jenis penyalut yang digunakan, dapat dilihat bahwa sorgum bar dengan penyalut nira tebu mengandung karbohidrat lebih tinggi, hal tersebut dikarenakan nira tebu memiliki kandungan gula lebih tinggi dibandingkan dengan penyalut yang lain.

\section{Kadar Serat Kasar Produk}

Serat kasar merupakan karbohidrat kompleks yang tidak dapat dicerna oleh tubuh manusia. Serat kasar terdiri atas selulosa, hemiselulosa, dan lignin (Sari, et al, 2015). Serat kasar menjadi bagian dari kadar karbohidrat dalam produk. 
Berdasarkan Tabel 2. Sorgum bar dengan penyalut nira sorgum memiliki kandungan serat kasar $0.94 \%$, sorgum puff yang mengandung serat kasar sebesar $0.93 \%$, sorgum bar dengan penyalut glucose syrup mengandung serat kasar sebesar $0.89 \%$, dan sorgum bar dengan penyalut nira tebu mengandung serat kasar sebesar $0.70 \%$. Pada penelitian sebelumnya, kadar serat kasar biji sorgum utuh sebesar $2 \%$, perbedaan data ini dikarenakan biji yang digunakan sebagai bahan baku pembuatan sorgum bar telah disosoh sehingga kadar serat kasar mengalami penurunan (Suarni, 2004).

\section{Karakteristik Subyek}

Metode purposive random sampling digunakan dalam merekrut subyek untuk uji indeks glikemik produk, yaitu komunikasi secara langsung untuk meminta kesediaan calon subyek. Calon sybyek sebelumnya telah dilakukan screening sesuai kriteria dari kuisioner yang diisi pada saat uji organoleptik. Calon subyek penelitian merupakan mahasiswa Universitas Brawijaya yang telah mendapatkan informasi secara lisan maupun tertulis dari peneliti dilanjutkan dengan penanda-tanganan informed consent. Subyek yang memenuhi kriteria inklusi, yaitu indeks massa tubuh normal (IMT $18.5 \mathrm{~kg} / \mathrm{m}^{2}-22.9 \mathrm{~kg} / \mathrm{m}^{2}$ dan Glukosa Darah Puasa (atau GDP) $<100 \mathrm{mg} / \mathrm{dl}$, tidak merokok atau minum alkohol, tidak mempunyai riwayat penyakit gangguan metabolisme seperti diabetes serta umur berkisar antara $20-30$ tahun (Avianty, 2014). Karakteristik subyek penelitian disajikan pada Tabel 3.

Pada Tabel 3. terlihat bahwa subyek berumur $21 \pm 0.5$ tahun, rerata IMT adalah 20.8 $\mathrm{kg} / \mathrm{m}^{2}$ dan gula darah puasa $91 \mathrm{mg} / \mathrm{dl}$. Semua subyek memenuhi kriteria yang ditetapkan.

Tabel 3. Karakteristik Subyek untuk Pengujian Indeks Glikemik Produk Sorgum Bar

\begin{tabular}{ccccccc}
\hline Subyek & $\begin{array}{c}\text { Jenis } \\
\text { Kelamin }\end{array}$ & $\begin{array}{c}\text { Umur } \\
\text { (tahun) }\end{array}$ & $\begin{array}{c}\text { BB } \\
\mathbf{( k g})\end{array}$ & $\begin{array}{c}\text { TB } \\
(\mathbf{c m})\end{array}$ & IMT* $\left.^{*} \mathbf{( k g} / \mathbf{m}^{2}\right)$ & $\begin{array}{c}\text { GDP } \\
(\mathbf{m g} / \mathbf{d l})\end{array}$ \\
\hline 1 & Wanita & 22 & 52 & 155 & 21.60 & 79.75 \\
2 & Pria & 22 & 67 & 170 & 24.20 & 81.25 \\
3 & Pria & 21 & 62 & 177 & 19.80 & 85.25 \\
4 & Pria & 21 & 55 & 169 & 19.30 & 84.75 \\
5 & Wanita & 22 & 57 & 163 & 21.50 & 97 \\
6 & Wanita & 21 & 51 & 159 & 20.20 & 93.75 \\
7 & Wanita & 21 & 48 & 160 & 18.80 & 97.25 \\
8 & Wanita & 21 & 45 & 156 & 18.50 & 98.25 \\
9 & Wanita & 21 & 57 & 160 & 22.30 & 93 \\
10 & Pria & 20 & 53 & 163 & 19.90 & 94.75 \\
11 & Pria & 21 & 59 & 172 & 19.90 & 87 \\
12 & Wanita & 21 & 56 & 158 & 22.40 & 101 \\
\hline
\end{tabular}

Keterangan :

BB: berat badan, TB: tinggi badan, GDP: gula darah puasa

IMT (Indeks Massa Tubuh) = rasio antara berat badan (dalam $\mathrm{kg}$ ) dengan kuadrat dari tinggi badan (dalam $\mathrm{m}^{2}$ )

\section{Penentuan Jumlah Pangan Uji}

Produk sorgum bar yang disukai konsumen yaitu yang mengandung $20 \%$ penyalut nira sorgum, nira tebu, atau glucose syrup diuji indeks glisemiknya dengan mengamati respon glukosa darah subyek selama 2 jam setelah mengkonsumsi sorgum bar. Porsi sorgum bar yang diberikan pada subyek harus mengandung $50 \mathrm{~g}$ available carbohydrate yang dihitung dari hasil uji karbohidrat by different dikurangi dengan kadar serat. Menurut Philippou (2016), perhitungan nilai indeks glikemik dilakukan dengan membandingkan kenaikan glukosa darah setelah mengkonsumsi produk yang mengandung $50 \mathrm{~g}$ available carbohydrate dengan kenaikan glukosa darah setelah mengkonsumsi $50 \mathrm{~g}$ glukosa murni. Jumlah per porsi produk sorgum bar dengan berbagai penyalut yang diberikan kepada subyek disajikan pada Tabel 4. 
Tabel 4. Penentuan Porsi Sorgum bar berbagai penyalut yang Setara dengan $50 \mathrm{~g}$ Available Carbohydrate

\begin{tabular}{lcc}
\hline \multicolumn{1}{c}{ Penyalut } & KH by different-Kadar serat (\%) & Porsi Sampel (g) \\
\hline Sorgum bar + & 82.25 & 60.80 \\
Nira Sorgum & & \\
Sorgum bar + Nira Tebu & 86.40 & 57.87 \\
Sorgum bar + Glucose Syrup & 85.90 & 58.20 \\
\hline
\end{tabular}

\section{Kadar Glukosa Darah}

Dalam penelitian ini sorgum bar diformulasi menggunakan 3 penyalut berbeda. Perbedaan penggunaan penyalut dalam pembuatan sorgum bar menghasilkan perbedaan respon glukosa darah pada semua subyek. Respon glukosa darah pada menit ke 0 (puasa) sampai dengan 2 jam setelah mengkonsumsi sorgum bar dengan berbagai penyalut disajikan pada Tabel 5. Respon glukosa darah ini digunakan untuk membuat kurva (Gambar 4) dan menghitung luas daerah dibawah kurva untuk perhitungan indeks glisemik. Karena parameter akhir/utama yang ditentukan adalah nilai Indeks Glikemik produk, sehingga uji statistik dilakukan hanya pada indeks glisemik masing-masing produk sorgum bar dengan berbagai penyalut (Tabel 6).

Tabel 5. Rerata Respon Kadar Glukosa Darah Subyek

\begin{tabular}{|c|c|c|c|c|c|}
\hline \multirow{2}{*}{$\begin{array}{l}\text { Pangan yang } \\
\text { dikonsumsi }\end{array}$} & \multicolumn{5}{|c|}{ Kadar Glukosa Darah (mg/dL) } \\
\hline & 0 menit & 30 menit & 60 menit & 90 menit & 120 menit \\
\hline $\begin{array}{l}\text { Glukosa anhydrat* } \\
\text { Sorqum bar + Nira }\end{array}$ & $95 \pm 11.36$ & $160.58 \pm 18.67$ & $150.75 \pm 29.00$ & $127.17 \pm 24.85$ & $111.58 \pm 30.82$ \\
\hline $\begin{array}{l}\text { Sorgum }{ }^{* *} \\
\text { Sorgum bar + Nira }\end{array}$ & $84.33 \pm 6.01$ & $109.42 \pm 12.62$ & $116.25 \pm 15.99$ & $97.67 \pm 10.89$ & $87.25 \pm 8.83$ \\
\hline $\begin{array}{l}\text { Tebu** } \\
\text { Sorgum bar }+\end{array}$ & $95.67 \pm 8.16$ & $122.92 \pm 16.98$ & $136.33 \pm 17.46$ & $112.25 \pm 13.68$ & $98.33 \pm 12.43$ \\
\hline Glucose syrup** & $90.92 \pm 7.57$ & $130.08 \pm 19.96$ & $148.08 \pm 24.47$ & $122.58 \pm 17.49$ & $104.92 \pm 17.79$ \\
\hline
\end{tabular}

Tabel 5. menunjukkan kenaikan kadar glukosa darah subyek 30 menit setelah mengkonsumsi bahan pangan acuan (glukosa anhidrat) maupun pangan uji (sorgum bar dengan berbagai jenis penyalut). Kadar glukosa darah pada pangan acuan/standar mulai turun pada menit ke-60, sedangkan pada pangan uji penurunan kadar glukosa darah mulai menurun pada 90 menit. Respon glukosa darah selama 2 jam dari menit ke 0 (puasa) dan setiap 30 menit setelah mengkonsumsi produk sorgum bar dengan berbagai jenis penyalut serta pangan acuan (glukosa anhidrat) dibuat grafik seperti pada Gambar 4.

Gambar 4. menunjukkan respon glukosa darah setelah mengkonsumsi pangan acuan dan pangan uji. Peningkatan respon glukosa darah pangan uji yang paling tinggi yaitu saat mengkonsumsi sorgum bar dengan penyalut glucose syrup dan peningkatan terendah yaitu pada sorgum bar dengan penyalut nira sorgum. Respon glukosa darah yang berbeda disebabkan oleh jenis available carbohydrate dan komponen lain yang ada dalam penyalut sorgum bar. Pada penyalut sirup glukosa, jenis available karbohidratnya adalah glukosa murni yang mendekati kemurnian larutan glukosa sebagai standar. Sehingga respon kenaikan glukosa darah paling tinggi diantara ketiga jenis penyalut. Sedangkan nira sorgum dan nira tebu berisi komponen available carbohydrate yang lebih beragam beserta senyawa-senyawa lain seperti polyphenol yang ikut terekstrak pada saat pengepresan batang sorgum dan batang tebu. Kenampakan nira sorgum yang lebih coklat menunjukkan banyaknya senyawa polifenol. Polifenol dilaporkan dapat menghambat aktivitas enzim $\alpha$-amilase dan amiloglukosidase yang berperan dalam pencernaan pati pada tikus diabetes (Shodehinde et al., 2015) sehingga, dalam hal ini polifenol berperan dalam mengurangi laju absorbsi glukosa. 


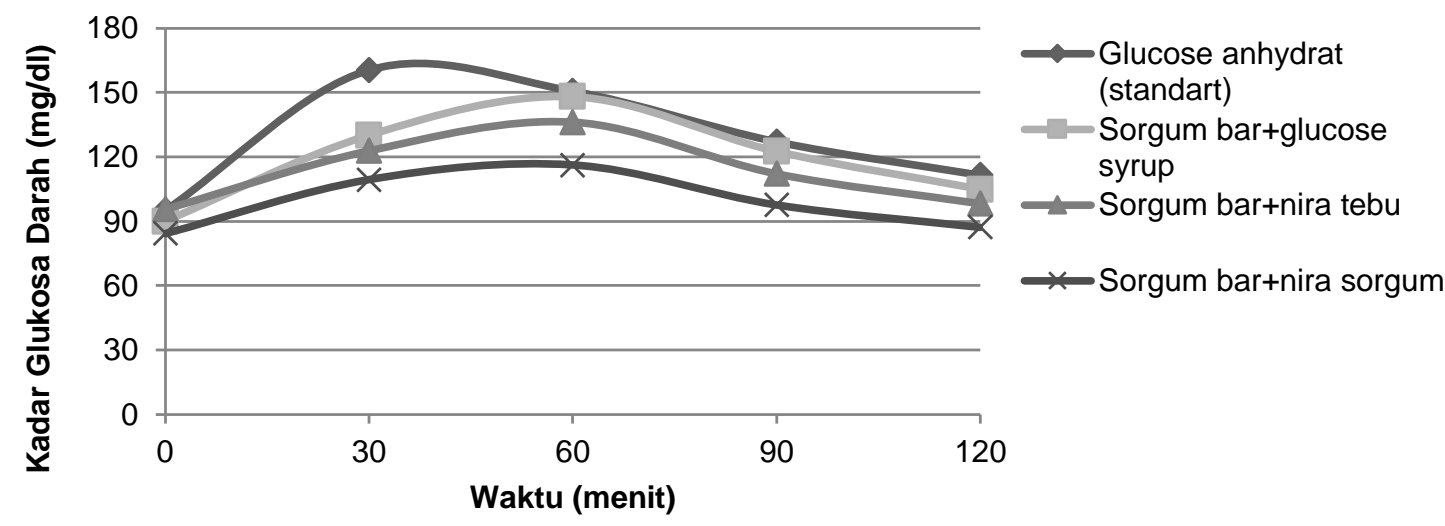

Gambar 4. Respon glukosa darah setelah mengkonsumsi pangan acuan (glucose anhydrat) dan pangan uji (sorgum bar dengan berbagai penyalut)

\section{Indeks Glikemik Produk Sorgum Bar}

Luas area di bawah kurva pada Gambar 4 digunakan untuk menghitung indeks glikemik produk. Luas area di bawah kurva respon glukosa setelah mengkonsumsi pangan uji (sorgum bar dengan berbagai penyalut) dibandingkan dengan luas area di bawah kurva respon glukosa setelah mengkonsumsi larutan glucose anhydrat (pangan acuan). Sorgum bar dengan berbagai penyalut mengandung available carbohydrate setara dengan 50 gram glukosa murni (pangan acuan), sehingga jika terdapat perbedaan indeks glisemik disebabkan oleh kandungan senyawa lain dalam penyalutnya. Menurut Rydon (2016), Available carbohydrate merupakan kandungan karbohidrat yang berupa gula sederhana yang biasanya terasa manis dan karbohidrat kompleks yang dapat diserap setelah dihidrolisis menjadi glukosa bebas selama proses pencernaan. Hasil analisis indeks glikemik produk sorgum dengan menggunakan beberapa jenis penyalut disajikan pada Tabel 6.

Tabel 6. Indeks Glikemik Produk Sorgum Bar menggunakan Beberapa Bahan Penyalut

\begin{tabular}{lccc}
\hline \multicolumn{1}{c}{ Jenis Penyalut } & Indeks Glikemik & Kategori $^{\star}$ & P value \\
\hline Sorgum bar + Nira & $44.73 \pm 8.83^{\mathrm{a}}$ & Rendah & 0.0001 \\
Sorgum & $53.72 \pm 3.63^{\mathrm{b}}$ & & \\
Sorgum bar + Nira Tebu & $81.41 \pm 8.17^{\mathrm{c}}$ & Rendah & \\
Sorgum bar + Glucose & & Tinggi & \\
Syrup & & \\
\hline
\end{tabular}

Keterangan: notasi berbeda pada parameter indeks glikemik menunjukkan perbedaan yang sangat nyata $(p<0.01)$. Kategori: Indeks Glikemik rendah $(<55)$, Indeks Glikemik sedang (5570), Indeks Glikemik tinggi (>70)

Tabel 6, menunjukkan bahwa nilai IG produk sorgum bar berbagai penyalut berbeda sangat signifikan $(p<0.01$ ). Indeks Glikemik tertinggi pada sorgum bar dengan penyalut glucose syrup dan terendah pada sorgum bar dengan penyalut nira sorgum. Indeks Glikemik merupakan suatu konsep diet terutama untuk membantu penderita diabetes melitus memilih makanannya dengan tujuan mengendalikan glukosa darah. Indeks Glikemik adalah respon kadar gula darah setelah mengkonsumsi pangan berkarbohidrat dengan jumlah tertentu yang diikuti oleh kenaikan respon insulin (Arif dkk, 2013). Karbohidrat yang dicerna dalam waktu yang cepat selama proses pencernaan menghasilkan peningkatan glukosa darah yang cepat sehingga pangan tersebut dikategorikan memiliki indeks glikemik yang tinggi, sebaliknya karbohidrat dalam makanan yang dicerna secara lambat maka menghasilkan peningkatan glukosa darah dan respon insulin yang lambat maka nilai indeks glisemik makanan tersebut rendah. Produk pangan yang memiliki nilai IG dikaterogikan menjadi pangan dengan nilai IG rendah (<55), IG sedang (55-75), dan IG tinggi ( $>75)$. Nilai indeks glikemik dapat dipengaruhi 
oleh faktor komponen dalam bahan seperti kadar serat, kadar protein, kadar lemak maupun faktor cara pengolahannya (Rimbawan dan Siagian, 2004).

Sorgum merupakan serealia yang tinggi protein (10.62\%) dan serat $(6.70 \%)$ (USDA, 2016). Kedua kandungan tersebut memiliki peran dalam menurunkan indeks glikemik produk pangan. Namun, indeks glikemik produk pangan juga dipengaruhi oleh proses pengolahan karena akan terjadi perubahan komposisi kimia. Proses pengolahan makanan dapat mengubah komposisi kimia pangan yang akan mempengaruhi proses penyerapan zat gizi dan indeks glikemiknya. Serat pangan mampu meningkatkan viskositas digesta, menyebabkan rasa kenyang yang lebih lama dan menurunkan laju absorbsi glukosa hasil pencernaan available carbohydrate sehingga akan menurunkan nilai IG suatu produk pangan Selain itu, protein juga dapat menurunkan nilai IG produk karena menunda pengosoangan lambung dan mempengaruhi laju absorbsi glukosa meskipun kurang signifikan. Faktor lain yang mempengaruhi nilai indeks glikemik yaitu komponen monosakarida, struktur pati, serta jumlah amilosa dan amilopektin (Wrigley, 2015). Namun dalam penelitian ini, produk sorgum bar yang diuji hanya berbeda dalam hal penyalutnya saja. Sehingga perbedaan nilai indeks glikemik lebih disebabkan oleh kandungan senyawa dalam penyalutnya.

Pada pembuatan sorgum bar menggunakan karamel yang terbuat dari nira sorgum dan nira tebu serta glucose syrup. Berdasarkan Tabel 6, produk sorgum bar yang memiliki indeks glikemik yang paling rendah yaitu sorgum bar dengan penyalut karamel nira sorgum. Hal ini dikarenakan nira sorgum memiliki kandungan gula sederhana yang paling rendah jika dibandingkan dengan kedua penyalut lainnya. Menurut Direktorat Jendral Perkebunan (1996), nira sorgum mengandung gula reduksi sebanyak 0.75-1.35\%.. Angka tersebut lebih rendah jika dibandingkan dengan nira tebu yaitu 0.48-1.5\%. Meskipun tidak berbeda signifikan namun akan mempengaruhi nilai indeks glikemik produk akhir. Selain itu nira sorgum yang lebih coklat menunjukkan banyaknya senyawa polifenol. Polifenol dilaporkan dapat menghambat aktivitas enzim $\alpha$-amilase dan amiloglukosidase yang berperan dalam pencernaan pati pada tikus diabetes (Shodehinde et al., 2015) sehingga, dalam hal ini polifenol berperan dalam mengurangi laju absorbsi glukosa.

\section{SIMPULAN}

Sorgum bar dengan penyalut karamel nira sorgum memiliki nilai indeks glikemik yang paling rendah diantara ketiga sorgum bar dengan perbedaan penyalut yaitu 45.04 (low-Gl product), sehingga sorgum bar dengan penyalut caramel nira sorgum dapat direkomendasikan sebagai alternatif makanan selingan bagi penderita DM tipe 2 sebagai upaya pengendalian kadar glukosa darah.

\section{UCAPAN TERIMA KASIH}

Penulis mengucapkan terimakasih kepada PT Nutrifood Indonesia selaku penyandang dana dalam program Nutrifood Research Center Grant 2018 No. SP/LG NFI-18/214, dosen pembimbing Ibu Dr. Siti Narsito Wulan, 80 panelis uji organoleptik dan 12 subyek terpilih yang berpartisipasi dalam pengujian indeks glikemik, para staf yang membantu di Poliklinik Universitas Brawijaya dan Laboratorium di Jurusan Teknologi Hasil Pertanian Fakultas Teknologi Pertanian Universitas Brawijaya dan berbagai pihak yang tidak dapat disebutkan satu persatu.

\section{DAFTAR PUSTAKA}

American Diabetes Association. 2012. Diagnosis and Classification of Diabetes Mellitus. Diabetes Care: Suplemen. Vol.35

Almatsier S. 2001. Prinsip Dasar IImu Gizi. PT Gramedia Pustaka Utama. Jakarta

Amanto, Sigit Bambang et al. 2015. Kinetika Pengeringan Temu Giring (Curcuma heyneana Valeton \& van Zijp) Menggunakan Cabinet Dryer Dengan Perlakukan Pendahuluan Blanching. Skripsi. Universitas Sebelas Maret. Surakarta 
Arif AB, Budiyanto A, dan Hoerudin. 2013. Nilai Indeks Glikemik Produk Pangan dan FaktorFaktor Yang Memengaruhinya. Jurnal Litbang Pertanian. Vol.32(3): 91 - 99

Avianty, S. dan Ayustianingwarno, F. 2014. Indeks Glisemik Snack Ubi Jalar Kedelai Hitam Sebagai Alternatif Makanan Selingan Penderita Diabetes Militus Tipe 2. Jurnal Aplikasi Teknologi Pangan. Vol.3(3): 98-102

Calbom, C. 2016. The Juice Lady's Sugar Knockout Detox to Lose Weight, Kill Cravings, and Prevent Disease. Siloam Publishing. USA

Direktorat Jenderal Perkebunan. 1996. Sorgum Manis Komoditi Harapan di Propinsi Kawasan Timur Indonesia. Risalah Simposium Prospek Tanaman Sorgum untuk Pengembangan Agroindustri, 17-18 Januari 1995. Edisi Khusus Balai Penelitian Tanaman Kacangkacangan dan Umbi-umbian. Vol (4): 6- 12

Franz, Marion J. 2008. Medical Nutrition Therapy for Diabetes Mellitus and Hypoglycemia of Nondiabetic Origin dalam Krause's Food \& Nutrition Therapy Edition 12. Saunders Elsevier. Canada

Goff, L., and Dyson, P. 2016. Advance Nutrition and Dietetics in Diabetes. John Wiley \& Sons, Ltd. New Jersey

Kementerian Pertanian (Kementan). 2015. Laporan Tahunan Direktorat Budidaya Serealia Tahun 2015. Diakses dari: http://sakip.pertanian.go.id/. Tanggal akses: 18/11/2019

Muchtadi, D., Astawan, M., dan Palupi, N.S. 2006. Metabolime Zat Gizi Pangan. Universitas Terbuka. Jakarta

Nabryzki, M. 2002. Mineral Components. Di dalam: Sikorski ZE. Chemical and Functional Properties of Food Components.2 nd Ed. Boca Raton: CRC Press. 51-79

Philippou, E. 2016. The glycemic index: applications in practice. CRC Press. Boca Raton

Rahman, M. H., dan Yuwono, S. S. 2019. Pengaruh Konsentrasi Zeolit dan Suhu Preheating dalam Proses Penjernihan Nira Sorgum Sebagai Bahan Baku Pembuatan Gula Cair. Jurnal Pangan dan Agroindustri 7:1. 39-47

Rakhmawati, F.K.R., Rimbawan., dan Amalia L. 2011. Nilai Indeks Glikemik Berbagai Produk Olahan Sukun. Jurnal Gizi dan Pangan. Vol. 6(1): 28-35

Rimbawan dan Siagian, A. 2004. Indeks Glikemik Pangan. Penebar Swadaya. Jakarta

Rufaizah, U. 2011. Pemanfaatan Tepung Sorgum (Sorgum bicolor L. Moench) Pada Pembuatan Snack Bar Tinggi Serat Pangan dan Sumber Zat Besi Untuk Remaja Putri. Skripsi. IPB. Bogor

Rydon, R., 2016. Profiles of the NutrientsÑ1. Carbohydrate, Lipid and Protein. Lulu. Com

Sari, M. L., Ali, A.I.M., Sandi S., dan Yolanda, A. 2015. Kualitas serat kasar, lemak kasar, dan BETN terhadap lama penyimpanan wafer rumput kumpai minyak dengan perekat karaginan. Jurnal pertenakan sriwijaya. Vol. 4, No. 2, desember 2015, pp. 35-40

Sari, D.Y.E., Angkasa, D., dan Swamilaksita, P.D. 2015. Daya terima dan nilai gizi snack bar modifikasi sayur dan buah untuk remaja putri. Universitas Esa Unggul. Jakarta

Septiani, V. E., Jus'at, I., dan Wijaya, H. 2012. Pembuatan Snack Bar Bebas Gluten dari Bahan Baku Tepung Mocaf dan Tepung Beras Pecah Kulit. Universitas Esa Unggul. Jakarta

S. A. Shodehinde, A. O. Ademiluyi, G. Oboh, A. A. Akindahunsi. (2015). Contribution of Musa paradisiaca in the inhibition of a-amylase, a-glucosidase and Angiotensin-I converting enzyme in streptozotocin induced rats. Life Sciences 133:8-14

Suarni. 2004. Pemanfaatan tepung sorgum untuk produk olahan. Jurnal Penelitian dan Pengembangan Pertanian. Vol. 23(4):145-151

Taylor, J. R. N., and Duodu, G. 2019. Sorgum and Millets: Chemistry, Technology, and Nutritional Attributes, Second Edition. Elsevier. Cambridge

USDA, Nutrient Data Laboratory, ARS. 2016. Basic Report : 20067, Sorgum grain. USDA National Nutrient Database for Standart Reference. Beltsville MD. https://plants.usda.gov/core/profile?symbol=SOBIB\#.16/10/201

WHO. 2016. Global Report On Diabetes. London: WHO Library Cataloguing Publishing Data

Wrigley, C.W., Corke, H., Seetharaman, K. and Faubion, J. eds., 2015. Encyclopedia of food grains. Academic Press. Cambridge 